UNTAG Law Review (ULREV)

Volume 1, Issue 2, Nov 2017, PP 1-9

ISSN 2549-4910 (online) \& ISSN 2579-5279 (print)

http://jurnal.untagsmg.ac.id/indeks.php/ulrev/indeks

www.fakhukum.untagsmg.ac.id

\title{
JUDICIAL REVIEW OF DISMISSION AND LIQUIDATION PROCESS FOR LIMITED LIABILITY COMPANY POST BANCRUPTCY
}

\author{
Bing Yusuf \\ Master of Law Universitas 17 Agustus 1945 Semarang \\ contact at email : untagsmg.com
}

\begin{abstract}
Starting from registration and licensing of the establishment until the end which is dismission and liquidation. From the beginning until the end of the existence of a Limited Liability Company, consists of many operational activities related to the business as regulated in Statute of Law Number 40 of year 2007 which legislate Limited Liability Company. At the end of the life cycle of the Limited Liability Company, there are three stages, they are dismission, liquidation, and ultimately revocation of the legal entity status of a Limited Liability Company. The main principle of this stage is as stated in a proverb on justice derived from Latin means that the basic principle of the law is to live a respectable life, not harming others, and to give others what is their due, so ideally the rule of law is implemented. In fact there is a dispute in the implementation of the stages of dismission, liquidation and revocation of legal entity status due to injustice and fraudulent acts committed by individuals, Therefore this research will be discussing the aspects that trigger the dispute, to the analysis on litigation process, and ultimately the researcher provides a solution to avoid the same disputes occur in accordance with the regulations of the Statute. This research was studied using descriptive analysis with normative juridical approach, supported by primary and secondary data source from literature study. It was found that the occurrence of a dispute was caused by an irresponsible director. Not responsible in carrying out his duties to do the General Meeting of Shareholders and submit the remaining treasury from bankruptcy process. Proceeded to the litigation process where the court declared that the court was not authorized according to relative competence in giving the decree of dismission. However, at the level of cassation, the decree was canceled. Problems as such should not occur in the first place if the director has been professional and responsible due to his duty.
\end{abstract}

Keywords: Conflict of interest, Dismission and Liquidation Process of Limited Liability Company.

\section{INTRODUCTION}

A Company is a business organization that can be made by individuals or groups for the purpose of conducting business. The company is known in Dutch as corporative which means business with legal status as a legal entity. ${ }^{1}$ Business defined in Statute of Law Number 3 of Year 1982 about the Obligation of Company Registration in Article 1 sub-article $d$ as any activity in the field of economy undertaken by any entrepreneur for the purpose of obtaining 
profit. In Article 1 sub-article d in Statute of Law Number 3 of Year 1982 there is mentioned the term of entrepreneur. Entrepreneur explained in Article 1 sub-article e that is any person or association or legal entity that runs a company A legally incorporated company including a Limited Liability Company.

The definition of Limited Liability Company is in Chapter I which is General Clause of Statute of Law Number 40 of Year 2007 about Limited Liability Company that is in Article 1 subarticle 1 which explains that Limited Liability Company is a legal entity established based on capital alliance, its establishment based on the agreement between the owners of capital. ${ }^{2}$ In the end Limited Liability Company will also be dismissed by the process of dismission and liquidation of Limited Liability Company which is regulated in Chapter X Article 142 until Article 152 about Dismission, Liquidation, and Revocation of Legal Entity Status in Statute of Law Number 40 of Year 2007 about Limited Liability Company. The explanation of Article 142 in the Statute of Law Number 40 of Year 2007 covers the provisions starting from the basis of dismission of Limited Liability Company until the implementation for liquidation process.

The process of dismission of Limited Livability Company and repayment of obligations of Limited Liability Company to all its creditors consist of two alternatives, it can be done through bankruptcy process and the other is the process of liquidation. There is a fundamental difference between the bankruptcy process and the liquidation process of a Limited Liability Company. The bankruptcy process of the Limited Liability Company are regulated in Statute of Law Number 37 of Year 2004 about Bankruptcy and Postponement of Debt Payment Obligations. In Article 142 sub-article 2 letter a explained that in the dismission of the company should be followed by the process of liquidation.

Sometimes before a Limited Liability Company is dismissed, bankruptcy process proceeds first because there are already two or more people who have receivables from related Limited Livability Company and petition for bankruptcy to the Commercial Court. The provisions concerning bankruptcy are regulated in Statute of Law Number 37 of Year 2004 about Bankruptcy and Postponement of Debt Payment Obligations. ${ }^{3}$ Bankruptcy itself is a process where there is a debtor declared bankrupt by the court, in this case, the authorized court is commercial court, because the debtor can not pay its debts, debtor's assets can be distributed to the creditors in accordance with the provisions in Statute of Law Number 37 of Year 2004.

In practice, case of liquidation process is hampered by the directors of the relevant Limited Liability Company, there is a problem where the board of directors or one of the directors allegedly committed an act against the law (Onrechtmatige Daad). Whereas in principle the of the civil law is stated in a Latin sentence that reads "Juris Praecepta Sunt Haec: Honeste Vivere, Alterum Non Laedere, Suum Cuique Tribuere" ${ }^{4}$, which, when translated into English, becomes the basic principle of the law is to live life appropriately, not harming others, and giving others what is rightfully theirs.

From the introduction above, the researcher will explore a case where the liquidation process from Limited Liability Company leads to a dispute that has been included in the litigation process up to the cassation level. This research is titled Judicial Review Of Dismission And Liquidation Process For Limited Liability Company Post Bankruptcy.

Basiang, Martin. 2014 Law Dictionary Second Edition. Gramedia Pustaka Utama, Jakarta.

2 Prasetya, Rudhi. 2014 Teori \& Praktik Perseroan Terbatas. Sinar Grafika, Jakarta.

3 Munir Fuady.2002 Hukum Kepailitan. Citra Aditya Bakti, Bandung.

4 Winarni, Luh Nila.2015 Asas Itikad Baik Sebagai Upaya Perlindungan Konsumen Dalam Perjanjian Pembiayaan, Jurnal Ilmu Hukum, Vol.11, No.21, Hal 1-12. Universitas Denpasar Bali, Denpasar. 
This research's objective is to understand how should dismission and liquidation process for Limited Liability Company to be carried out in order to avoid dispute. The case of dismission and liquidation process in this research is taken from an example of PT.V (PT.V was a Limited Liability Company which was originated in West Jakarta at Daan Mogot street). According to North Jakarta District Court Decision Number341/Pdt.P/2013/PN.Jkt.Ut., and Decision of Cassation Number 344K/PDT/2014, parties in dispute are :.

1. RS (Petitioner and Cassation Petitioner)

RS is a commissioner of PT.V who is also a shareholder of PT.V which has 760 (seven hundred sixty) shares which value is equivalent to Rp. 380.000.000,- (three hundred eighty million rupiah).

2. S(Pleated and Cassation Pleated)

$\mathrm{S}$ is a director of PT.V who is also a shareholder of PT.V which has 1,140 (one thousand one hundred forty) shares equivalent to Rp. 570.000.000, - (five hundred seventy million rupiah).

Basic reasons of PT.V's dismission is because based on facts and evidence based on the Decision of the Cassation, the dismission of PT.V is classified as dismission based on the stipulation of the court which is regulated in Statute of Law Number 40 of Year 2007 Article 142 sub-artice 1 letter c. ${ }^{5}$ The cornerstone for the dismission of PT.V is regulated in Statute of Law Number 40 of Year 2007 Article 146 sub-article 1 letter c where the dismission is done based on the stipulation of the District Court. The situation of PT.V that cannot operate further is explained in the Stipulation of North Jakarta District Court Number 341 / Pdt.P / 2013 / PN.Jkt.Ut. in various reasons:

1. PT.V was no longer conducting business or being in a non-active condition for more than three years.

2. Most of the shareholders' addresses are no longer known even though it has been invoked through the advertisement in the newspaper so Shareholders General Meeting of PT.V can not be executed.

3. Due to the balance of ownership of shares in PT.V resulting in the General Meeting of Shareholders cannot take dominant decisions based on voting so that a legitimate decision cannot be concluded.

4. Because the wealth of PT.V has been reduced so it is considered no longer possible to continue it's business activities.

\section{DISCUSSION AND ANALYSIS}

The aspects that trigger the dispute in the process of dismission and liquidation of PT.V where the directors are also shareholders.

The beginning of dispute is because PT.V is no longer operating or running business since 2008 and every financial activity implemented and handled by RS and S as the Commissioner and Director of PT.V. In 2009 PT.V was sued for bankruptcy by PT.ITS and terminated bankrupt based on Decision of Commercial Court Number 2 / Pailit / 2009 / PN.Niaga. JKT.PST. Then PT.V's obligations towards it's creditors are settled through the curator's services by disbursing and selling PT.V. assets. After the curators finished their work, there was found a residue of the sale of PT.V assets and the settlement of obligations amounting to Rp. 9.359.487.108, -

The occurrence of a dispute is because the RS realizes that the remaining money from the

5 Qomarudidin. 2017 Pendidikan Profesi Likuidator Indonesia. PPLI, Jakarta. 
selling of assets and repayment of obligations in the process of bankruptcy is controlled by S. $\mathrm{RS}$ had asked for an explanation and follow-up to $\mathrm{S}$ regarding the remainings of the bankruptcy process and S did not respond. Based those reasons RS concludes that $\mathrm{S}$ is no longer have good intentions and actually cheated on the possession of the sale of assets that have now become PT.V cash assets and do not intend to divide the remaining assets of PT.V in accordance with the portion to the Shareholders.

RS as commissioner was trying to summon the board of directors, commissioners and shareholders to conduct the General Meeting of Shareholders to discuss the dismission and termination of Status of of PT.V as Legal Entities. It turns out that based on the statement of the case in the Cassation Decision there are only two individuals who are still active and known existence in the operation of PT.V. RS as commissioner of PT.V is also a shareholder of 760 (seven hundred and sixty) shares of equivalent value of Rp. 380.000.000, - (three hundred and eighty million rupiah). S as the director of PT.V which is also a shareholder of 1,140 (one thousand one hundred forty) shares worth equivalent to Rp. 570.000.000, - (five hundred seventy million rupiah).

The above statement provides information that the share ownership position of each individual is $570,000,000$ versus $380,000,000$. If calculated to be a percentage of share ownership then RS owns $40 \%$ of PT.V and S shares owns $60 \%$ shares of PT.V. Recalling that the RS intends to conduct a General Meeting of Shareholders to take the shareholders' policy to dismiss and revoke the status of legal entity of PT.V, it must be viewed in accordance with the provisions in the in Statute of Law Number 40 of Year 2007 of Chapter VI concerning the General Meeting of Shareholders. ${ }^{6}$

Based on the explanation in the Cassation Decision concerning the sitting of the case, it was found that in the establishment and determination of the Articles of Association of PT.V has been determined on the basis of mutual agreement of shareholders concerning the provisions of the quorum. This indicates that PT.V is subject to Statute of Law Number 40 of Year 2007 Article 89 sub-article 1 stating the General Meeting of Shareholders if it is done in order to approve the Merger, Consolidation, Takeover or Separation, the application for the Company to be declared bankrupt, the extension of the period of its establishment and the dismission of the Company shall be held in the General Meeting of Shareholders at least 3/4 (three quarters) of the shareholders. The validity of the General Meeting of Shareholders decision shall be approved if at least $3 / 4$ (three quarters) of the total votes cast. ${ }^{7}$ Specifically for the case of PT.V where there is already a provision in the articles of association concerning the quorum shall be granted an exemption whereby if within the Articles of Association the enterprise says otherwise.

The Articles of Association of PT.V in Article 10 specify that the General Meeting of Shareholders which may be said fulfilling the quorum requirements to take the policy of PT.V if attended by $2 / 3$ (two thirds) of the shareholders who have voting rights. ${ }^{8}$ PT.V left only two shareholders which resulted in non-fulfillment of quorum requirements of PT.V as specified in the Articles of Association of PT.V. The two persons are RS which is a commissioner and shareholder of $40 \%$ and $\mathrm{S}$ who is a director and shareholder of $60 \%$. In accordance with the above explanation it is clear that although the shareholders of PT.V conduct the General

6 Saliman, Abdul R. Hukum Bisnis Untuk Perusahaan Teori dan Contoh Kasus Cetakan Kelima. Prenadamedia Group, Jakarta. 2015.

7 Prasetya, Rudhi. Teori \& Praktik Perseroan Terbatas. Sinar Grafika, Jakarta. 2014

8 Harahap, M. Yahya.2016 Hukum Perseroan Terbatas. Sinar Grafika, Jakarta. 
Meeting of Shareholders, then it will not be valid because the share ownership can be said to be almost balanced with a ratio of 6: 4 (six to four). This resulted in the dismission decision of PT.V cannot be concluded by General Meeting of Shareholders, and so it can only be implemented through the Court Decision.

If the execution of the General Meeting of Shareholders does not occur and does not meet the minimum requirement for quorum, resulting in the legal basis of dismission and liquidation of PT.V does not use Statute of Law Number 40 of Year 2007 Article 142 sub-article 1 letter a stating that the basic dismission PT is due to the General Meeting of Shareholders agreement. Another way to apply for the determination of the PT in liquidation status is through the Stipulation of the District Court. If PT.V obtains the status of PT in liquidation in accordance to Stipulation of District Court, PT.V is dismission is regulated in Statute of Law Number 40 of Year 2007 Article $142 \mathrm{sub}$ article 1 letter c stating that the legal basis for dismission of PT is through Court Decision. However, it has not yet reached the request of the State Court Decision and not even until the implementation of the General Meeting of Shareholders the process of dismission and liquidation of PT.V is hampered.

$\mathrm{S}$ who held the position as the director of PT.V and also as one of its shareholders did not provide accountability report of the liquidation process and also did not submit part of the remaining cash from bankruptcy process of Rp. 9.359.487.108, - to be divided in accordance with the rights of each shareholder. S did not respond to a call from RS to fulfill the shareholder's rights. Whereas already stipulated in the Articles of Association of PT.V as stipulated in the Notary Act in Article 15 sub-article 2 which requires the director to provide an explanation of all matters asked by the Board of Commissioners. By not giving accountability report then $\mathrm{S}$ also violate the provisions contained in the Articles of Association of PT.V.

$\mathrm{S}$ as the board of directors has an obligation to hold the General Meeting of Shareholders. If the dismission implementation is based on the resolutions of the General Meeting of Shareholders so dismission and liquidation process of PT.V can be done swiftly. Director of a PT has an obligation to hold a General Meeting of Shareholders when there is agreement to organize a deliberation to decide the dismission of PT which then proceeded to the process of liquidation and revocation of Limited Liability Company as legal entity. ${ }^{9}$ The Director shall make the invitation of the General Meeting of Shareholders pursuant to Statute of Law Number 40 of Year 2007 Article 82 sub-article 2 that is using Letter of Registration or Newspaper Advertising, and based on Statute of Law Number 40 of Year 2007 Article 82 subarticle 3 in the invitation of the General Meeting of Shareholders must include the date, time, place, and eyes of the meeting with notice that the material to be become the topic of the General Meeting of Shareholders is provided in the office of the Limited Liability Company from the date of the summon up to the date of procurement of the General Meeting of Shareholders.

$\mathrm{S}^{\prime}$ action such as those explained above is actually prohibited in accordance with the provisions set forth in the Statute of Law Number 40 of Year 2007 Article 92 sub-article 1 which regulates that the Board of Directors has an obligation to conduct management in the interest of Limited Liability Company in accordance with the purpose and objectives of the Limited Liability Company. The provision is emphasized again on Statute of Law Number 40 of Year 2007 Article 97 sub-article 1 and 2 where it is stipulated that the Board of Directors is responsible for the management of Limited Liability Company as referred to in article 92 subarticle 1, and in conducting the management of Limited Liability Company directors must do

9 Asyhadie, Zaeni; Sutrisno Budi 2012. Hukum Perusahaan \& Kepailitan. Penerbit Erlangga, Jakarta. 
so on the basis of good intentions and full of responsibility. ${ }^{10}$

Mr. Azzet Hutabarat provides an appropriate explanation of his condition with the liquidation case that occurred on PT.V, he stated thus:

"A dispute is up to things like, let's imagine if it's like a cake if it's fair share it would not be a problem, if someone does not get their fair share then it could be a problem, so as long as it goes as how it should be and everyone is happy with it, there should not be a problem."

Based on the statement from Mr. Azzet Hutabarat above it can be understood that the problems in the process of dismission and liquidation of PT.V is because the process did not proceed properly, causing problems in the form of dispute between the commissioner PT.V which is also a shareholder, with the director of PT.V which is also a shareholder. RS as the party that right is aggrieved by the acttions of $\mathrm{S}$ as the director.

The statement from Mr. Azzet Hutabarat was reinforced by a statement from Dr. M.Achsin where he stated that if the director of the company carried out the liquidation process incompetently, the risk of a dispute arose. He then explained thus:

"If the boedel or assets of Limited Liability Company are sufficient then there is little possibility of a dispute, unless the directors are incompetent in performing their duties in the liquidation process."

In the case of PT.V, S being the representative of the company that should perform its responsibilities as a director by giving the report precisely perform unprofessional action by not giving report to other shareholder that is RS who held position as company commissioner and also a shareholder. If from the beginning $\mathrm{S}$ as director who kept the money left over from the bankruptcy process reported to the commissioners or to other shareholders, such dispute will not occurred in the first place. However, because $\mathrm{S}$ does not have the good intentions to give a report on the money of Rp. 9.359.487.108, - which was in his possession and submits it to the General Meeting of Shareholders forum to be divided according to the proportion of shareholders, a dispute arises between the RS as a commissioner and shareholder, and $\mathrm{S}$ as a director and shareholder.

$\mathrm{S}$ as the director has a conflict of interest because $\mathrm{S}$ is also a shareholder, and it would be difficult to be objective and neutral in terms of the distribution of the cash residue of the bankruptcy process to other shareholders. From the beginning $\mathrm{S}$ who has the position of director and also as the shareholder is not allowed to control the residual property of bankruptcy proceeds based on the provisions in Statute of Law Number 40 of Year 2007 Article 99 sub-article 1 letter $b$ states that members of the Board of Directors are not authorized to represent the company if the member of the Board of Directors has a conflict of interest. ${ }^{11}$ Conflict of interest by $\mathrm{S}$ in this case that is with $\mathrm{S}$ controlled treasure the rest of bankruptcy proceeds in the property of $\mathrm{Rp}$. 9.359.487.108, - where such property is partly his property. It is not allowed for a person who has a share of property in the Limited Liability Company to control the rights of other shareholders which has not been distributed according to the proportion.

10 Asyhadie, Zaeni. 2014. Hukum Bisnis Prinsip dan Pelaksanaanya di Indonesia. RajaGrafindo Persada, Jakarta.

11 Wahyudi, Rachmad. 2017 Konsep Desain \& Praktik Tahapan Likuidasi (Perencanaan; Pelaksanaan; Pengakhiran \& Pemberesan). PPLI, Jakarta. 


\section{The best solution regarding the dismission and liquidation process at PT.V to avoid any dispute.}

Given the initial appearance of the dispute on the process of liquidation PT.V is preceded because of the proportion of equitable shareholding between the two remaining shareholders. The shareholder also serves as an organizational structure of the Limited Liability Company where RS serves as a commissioner and also as shareholder with shares of 760 (seven hundred and sixty) shares equivalent to Rp. 380.000.000, - (three hundred and eighty million rupiah). S as the director of PT.V who is also a shareholder of 1,140 (one thousand one hundred forty) shares worth equivalent to Rp. 570.000.000, - (five hundred seventy million rupiah).

This balanced shareholding is unfavorable when there is a difference of opinion if the General Meeting of Shareholders of PT.V wishes to take a policy in the General Meeting of Shareholders because it will be very difficult to meet the quorum requirements in the two executions of the General Meeting of Shareholders. The difficulty of fulfilling quorum requirements is due to the requirement of the General Meeting of Shareholders in order for the quorum at the first General Meeting of Shareholders to be held in particular to take the policy of the Limited Liability Company shall be attended at least 3/4 (three) have a voting right present in the General Meeting of Shareholders implementation. Then the quorum requirement determining the validity of the resolutions of the General Meeting of Shareholders is approved by at least 3/4 (three fourths) of the total number of votes issued between the Merger, Consolidation, Takeover or Separation, the application for the Company to be declared bankrupt, the extension of the term of establishment, and the dismission of the Company. Seeing the provisions on Statute of Law Number 40 of Year 2007 Article 89 subarticle 1 this can be said that if the RS who want to conduct General Meeting of Shareholders whose purpose is to dismiss the Limited Liability Company. it becomes impossible to meet quorum requirements. This is because $\mathrm{S}$ as the director and shareholder ignored the calling of the General Meeting of Shareholders, while S owned a majority share of $60 \%$ of all shares of stock.

If S with good intentions performs his duty to attend the General Meeting of Shareholders to adopt the policy of dismission of PT.V. It will not be a problem because the General Meeting of Shareholders is affiliated by $100 \%$ or all parties owning shares of PT. It still does not change the fact although PT.V has its own Articles of Association of PT.V in Article 10 that regulates the requirement of quorum in General Meeting of Shareholders which is is the presence of $2 / 3$ (two thirds) of all shareholders who have voting rights in the General Meeting of Shareholders, the result would still be the same. The dispute in the process of liquidation PT.V would not happen if S as director and shareholder who kept the rest of the cash of bankruptcy process of PT.V willingly cooperate for the goal to dismiss and liquidate PT.V. Because PT.V has been declared bankrupt and has not operated for a long time then PT.V must carry out the liquidation process.

\section{CONCLUSION}

The dispute above would not occur if $\mathrm{S}$ was responsible by submitting the remaining bankruptcy process assets of PT.V and attending the General Meeting of Shareholders to present his accountability report and aggreed to dismiss PT.V and divide the remaining bankruptcy property in accordance with the proportion of shareholders. But it would be quite difficult because $S$ basically has conflict of interest. So according to Statute of Law Number 40 of Year 2007 Article 99 sub-article 1 letter b which prohibits members of the Board of Directors to represent the company if the member of the Board of Directors has a conflict of 
interest. So it would be important to have a third party that is neutral, fair, and most importantly impartial. Statute of Law Number 40 of Year 2007 Article 142 sub-article 2 letter a stated that dismission of Limited Liability Company have to be followed by liquidation process undertaken by liquidator or curator. Board of directors or a director may become a liquidator of the Limited Liability Company where he works. But in the case of PT.V, S as the director also has a share of shares, so $\mathrm{S}$ is not allowed to become a liquidator of PT.V.

\section{RECCOMENDATION}

The best solution is RS and S carry out General Meeting of Shareholders to homologate that PT.V is dismissed and should undertake liquidation process. In that very same General Meeting of Shareholders, RS and S can appoint third party to execute the liquidation process. This third party should not be associated to PT.V's individuals in it's organizational structures. There is a newly developed certivied profession under the patronage of Perkumpulan Profesi Likuidator Indonesia which abbreviated to PPLI. In the future, to avoid disputes such as experienced by shareholders of PT.V, a professional third party that is trained, and expert in dismission and liquidation process should be appointed.

\section{REFERENCES}

Ali, Zainuddin. 2016. Metode Penelitian Hukum. Sinar Grafika, Jakarta.

Asyhadie, Zaeni. 2014. Hukum Bisnis Prinsip dan Pelaksanaanya di Indonesia. Raja Grafindo Persada, Jakarta.

Asyhadie, Zaeni; Sutrisno Budi. 2012.

Hukum Perusahaan \& Kepailitan. Penerbit Erlangga, Jakarta.

Basiang, Martin. 2014.Law Dictionary Second Edition. Gramedia Pustaka Utama, Jakarta.

Clarkson, Kenneth. W.; Miller, Roger; Cross, Frank. B. 2012.Business Law Text And Cases. Legal., Ethical., Global., and Corporate Environment. Cengage Learning, Mason.

Harahap, M. Yahya. 2013.Hukum Acara Perdata. Sinar Grafika, Jakarta.

Harahap, M. Yahya. 2013. Hukum Perseroan Terbatas. Sinar Grafika, Jakarta.

Lisdiyono, Edy. 2016.Kapita Selekta Hukum Perdata. Penerbit Pustaka Magister, Semarang.

Mertokusumo, Sudikno. 2014. Hukum Acara Perdata Indonesia. Universitas Atma Jaya Yogyakarta, Yogyakarta.

Muhammad, Abdulkadir. 2010. Hukum Perusahaan Indonesia. Citra Aditya Bakti, Jakarta.

Munir Fuady. 2002.Hukum Kepailitan. Citra Aditya Bakti, Bandung.

Prasetya, Rudhi. 2014.Teori \& Praktik Perseroan Terbatas. Sinar Grafika, Jakarta.

Purwosutjipto, H.M.N. 2007. Pengertian Pokok Hukum Dagang Indonesia 1: Pengetahuan Dasar Hukum Dagang. Djambatan, Jakarta.

Qomarudidin. 2017.Pendidikan Profesi Likuidator Indonesia. PPLI, Jakarta.

Saliman, Abdul R. 2015.Hukum Bisnis Untuk Perusahaan Teori dan Contoh Kasus Cetakan Kelima. Prenadamedia Group, Jakarta.

Saliman, Abdul R. 2016. Hukum Bisnis Untuk Perusahaan Teori dan Contoh Kasus Cetakan Keenam. Prenadamedia Group, Jakarta. 
Subekti. 1989Hukum Acara Perdata. Bina Cipta, Bandung.

Suharni. 2016. Hukum Dagang dan Bentuk Perusahaan (Edisi Revisi Ke-2). Universitas 17 Agustus 1945 Semarang, Semarang.

Tedjosaputro, Liliana. 2015. Kejahatan Profesi. Universitas 17 Agustus 1945 Semarang, Semarang.

Wahyudi, Rachmad. 2015.Konsep Desain \& Praktik Tahapan Likuidasi (Perencanaan; Pelaksanaan; Pengakhiran \& Pemberesan). PPLI, Jakarta. 2017.

Winarni, Luh Nila. 2015.Asas Itikad Baik Sebagai Upaya Perlindungan Konsumen Dalam Perjanjian Pembiayaan, Jurnal Ilmu Hukum, Vol.11, No.21, Hal 1-12. Universitas Denpasar Bali, Denpasar. 